[Amalas N. Y. ACAD. SCI., Vol. XIII, No. 5, pp. 387-418, Jan, 14, 1901.]

\title{
A RECONNOISSANCE OF THE ELIZABETH ISLANDS
}

ARThUR HoLlick.

(Read May is, ilog)

[Plates VIII-XV]

CONTENTS

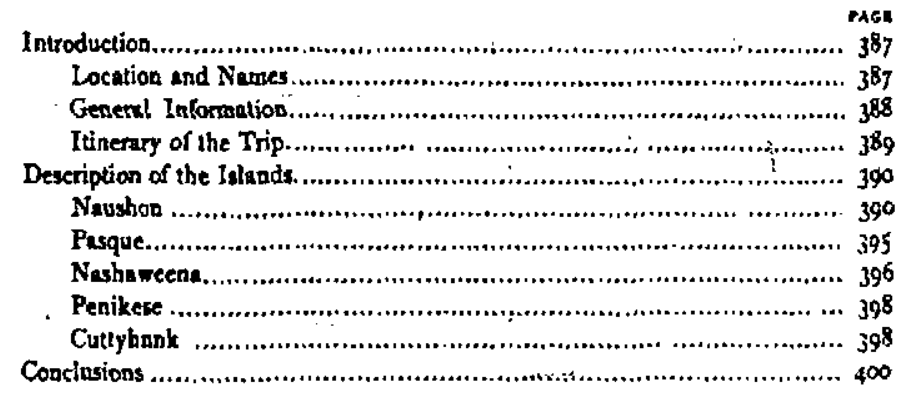

\section{INTRODUCTION}

\section{Location and Fames}

The Elizabeth Islands, as understood by that name at the present day, comprise the group which extends in a southwesterly direction, for a distance of about sixteen miles, from Wood's . Hole, Mass., forming the barrier between Buzzard's Bay on the north and Vineyard Sound on the south; although formerly Martha's Vineyard and its adjoining islands of Chappaquidick and No-Man's Land, seem to have been included under the same name. The principal islands of the group are five in number, besides which there are numerous smaller islands, some of them but little more than isolated heaps of bowlders. Beginning at the eastern end the five are known, in sequence, as Naushon, inciuding Nonamessețt, Uncatisa, Pine Island, Buck Island 
and the Weepeckets ; Pasque ; Nashaweena ; Penikese, including Gull Island; and Cuttyhunk. Together they constitute the Town of Gosnold and are included with Martha's Vineyard in the County of Dukes, State of Massachusetts.

The names by which the islands are known are of indian origin, but nearly all have undergone more or less change or modification since the time of the aboriginal designations. In an old history of the region ${ }^{1}$ may be found the following information relating to them:

\section{Modern Names}

Elizabeth Islands.

Naushon, Naushuan.

Nonamessett, Monomessett.

Uncatina, Onkatonka.

Pasque, Pesque.

Nashaweena.

Penikese, Peniquese.

Cuttyhunk.

\section{INDIAN NAMES}

Nashanow Islands.

Katomuck.

Nanomeesett.

Uncatincett.

Peshchameesett, Pesquineese.

The latter also appears to have been known as the original Elizabeth Island, before the name was made to include the entire group.

It may perhaps also be of interest to note that the name Buzzard's Bay is said to have been derived from "Buzzardet" or little buzzard, the name under which the fish hawk was formerly known and which were very abundant there.

The name Weepecket is supposed to be a corruptiom of "Wabacuck," the Indian name for the bald eagle.

\section{General Informstion}

The islands had attracted my attention and had aroused my curiosity and interest for some time, partly because little or nothing had been written in regard to them ${ }^{2}$ and partly for the

'The History of New Bedford, Bristol County, Massucbusetts, ete. Doniel Ricketson. New Bedford, 1858.

"The earliest reference which I have been able to discover is entitled "Notices on the Geology of tierthe's Vineyard and the Elizabetb Islands," by Euwaso Hirchcock, in $A m$. Jourm. Sci., vii. (1824), 240-248, but the geological fentures were merely noted by him in passing by the islands and they are exceedingly brief and superficial. 
reason that definite information in relation to them was necessary as a logical sequence to my previous investigations in the vicinity, on Long Island, Block Island, Martha's Vineyard and Nantucket. This entire region was recognized as having been involved in one series of cause and effect, especially during the Quaternary and modern periods, so that any new facts in regard to any portion of the region would be of importance in arriving at final conclusions in regard to the whole.

When I came to look into the matter, however, I found that the proposed trip was not without certain difficulties. Each island is owned by some one individual, family or corporation, with the exception of Cuttyhunk, upon which there are a number of separate holdings, hence there is no line of public travel to or through the group, no public conveyances and no houses of public entertainment, except in connection with Cuttyhunk, and consequently any stranger desiring to explore the group must be dependent upon the good will and courtesy of the owners for both transportation and subsistence.

As soon as my object became known, however, every possible facility was placed at my disposal, and in this connection I wish to acknowledge my indebtedness to Mr. J. Malcolm Forbes ; to Mr. J. Crosby Brown and other members of the Pasque Island Club; to Mr. Edward B. Merrill; to Mr. Geo. S. Homer; and to $\mathrm{Mr}$. Wm. A. Woodhull and other members of the Cuttyhunk Club, for facilities and courtesies extended to me respectively on Naushon, Pasque, Nashaweena, Penikese and,Cuttyhunk, without which facilities and courtesies the trip as finally accomplished would have been impossible.

\section{Itinersry of the Trip}

The trip occupied exactly a week, from August Io, 1898, to August I6th, inclusive. It was begun at the eastern end, at Wood's Hole, from whence the Forbes' steam launch was the means of transportation from the mainland to Naushon, where accommodation was provided for me at the farm house.

August IIth was spent on foot, exploring Nonamessett and Uncatina. 
August 12 th a horse and wagon was placed at my disposal, by which means I was enabled to drive through Naushon, from end to end, under the guidance of .Mr. Frederick H. Lambert, the overseer, and to reach Pasque by rowboat on the same day, where the Pasque Island Club extended its priviledes to me.

August 13th was devoted to an exploration of Pasque on foot, after which a sailboat was provided on which I was transported to Nashaweena, where I was received as the guest of Captain John E. Johnson, the representative of the owner.

August 14th was spent on horseback, under the guidance of Captain Johnson, traversing the shore line of Nashawena, with occasional diversions inland.

August 15 th was occupied in sailing to Penikese, where about three hours were given to an examination of the island on foot, and thence, again by sailboat, to Cuttyhunk, where I was the guest of the Cuttyhunk Club.

The remainder of the I 5 th and part of the 16th of August were utilized in field work on Cuttyhunk, after which the regular steamboat was taken to New Bedford.

\section{DESCRIPTION OF THE ISLANDS}

[Map, Plate XV.]

\section{Naushon}

This island, owned by the Forbes family, is the largest of the group, having a length of about eight miles and averaging about one and one-half mile in width. Uncatina and Nonamessett are joined with it by means of causeways. It is the only one from which the trees have not been removed, and, fortunately, those who have been in possession since the early days-the Winthrops, Swaynes, Bowdoins and Forbes-have keenly appreciated the beauty of natural surroundings and in consequence the larger part of the island is yet covered by a forest growth of primeval wildness, which is jealously preserved from either the destructive attacks of the utilitarian or the conventionalizing of the landscape architect. Even the few roads, which of necessity 
have been laid out, are to a great extent but little more than well-cleared wagon tracks, which follow the natural winding contours of the surface, or occasionally curve or twist in an unexpected manner, in order to avoid the destruction of, or to bring into view, some striking feature, such as a large tree or bowlder.

The forest growth was a revelation, as most of it had all the appearance of never having been disturbed by civilization. The trees are in every stage of growth, from seedlings and small saplings to those which are in their prime or past it, while lying on the ground, where they have fallen naturally, are the decaying trunks of former generations.

Taken as a whole the arborescent flora is similar to that of the mainland adjacent, and there is as much difference between it and that of Martha's Vineyard, only about four miles distant, as there is between the flora of the New Jersey highlands and that of the pine barrens. There are a few scattered individuals of Pinus rigida Mill., and $P$. sylvestris $\mathrm{L}$. has been introduced and planted to a considerable extent, but aside from these two species the trees are almost wholly deciduous, consisting largely of Fagus Americana Sweet., Quercus alba L, $Q$. mbra L., $Q$. velutina Lam., and a plentiful sprinkling of Ostrya Virginiana (Mill.) Willd. There are a few good sized individuals of $l l e x$ opaca Ait, widely separated, and Cytissus seoparius (L.) Link. has been planted over quite extensive areas, formerly denuded, in order to secure a quick growth of vegetation. This did not appear to be in a very thriving condition however, and in places large patches had apparently died out completely. The arborescent feature, however, which is sure to attract immediate attention is the great abundance of beeches. In certain sections there are acres of the forest where this tree monopolizes fully ninetenths of the growth, and a complete tree census of the island would undoubtedly show it to be in a considerable majority.

On the outskirts of the forest, or where isolated individuals or clumps of trees accur, a remarkable effect of the winds may be seen. The branches on the side exposed to the -unbroken winds are short and stunted, while to the leeward they are 
elongated and stretch out often to extraordinary lengths. The trees present the appearance of having been artifically trimmed on the windward side so that only half the tree remains. This feature is particularly conspicuous on windward slopes, where the long leeward branches of large trees often extend out and droop until they rest upon or nearly touch the ground thirty or forty feet distant from the trunk, while where the trees grow in hollows or depressions the force of the winds checks the upward growth as soon as it reaches the level of the surrounding hills, leaving a remarkably uniform surface over the entire mass of the tree tops.

Another peculiar effect is also produced by these conditions in the relative heights of trees. The trunks of those which grow in the bottom of any depression are tall, while those on the sides are successively shorter and shorter, according as their location approaches the summit, although the diameters of the trunks may vary but little. Many individuals may thus be singled out in which the lateral extent of the branches is out of all proportion to the height or diameter of the trunk, giving a most weird and peculiar appearance to the tree. These phenomena due to wind action are particularly conspicuous on the south side of the island, which is exposed to the full force of the ocean storms. [Rlate VIII.]

The denuded areas present but few botanical features which differ from thase of similar morainal areas on the adjoining mainland. They are wind-swept and almost destitute of any conspicuous vegetation except for patches of Myrica cerifera L., and stunted growths of Vaccinium and Gaylussacia. Euthamia Caroliniana (L.) Greene seemed to be about the most abundant or conspicuous herbaceous plant in such situations, at the time of my visit.

A species perhaps wortny of special mention is a form of Plantago major L., found on Uncatina. It was in conșiderable abundance, although apparently restricted in its habitat to a zone located just above high-water mark. My attention was at once attracted to it by reason of its lanceolate 3-nerved leaves and the fact that the entire plant was more or less covered by a 
short hoary pubescence. More extended examination may prove it to be worthy of varietal rank.

The island is composed of a series of rounded morainal hills, with a maximum elevation of 160 feet. Many of the depressions are amphitheater-like in form, in some of which there are swamps or ponds, often without visible outlets. One of these is occupied by West End Lake, a body of clear fresh water, some 45 acres in area, the surface of which is usually about 5 feet above tide level, while the bottom is said to be about 75 feet below. At the time of my visit a considerable stream was flowing from it, although this was stated to be not always the case and due to the unusually wet season and recent heavy rains. In its general features it is strikingly like Lake Ronkonkoma on Long Island and is evidently caused by similar morainal conditions. Its limited drainage area would, alone, be insufficient to account for the almost uniform level maintained by the water, but the depth. of the basin, and its nearness to tide water at once suggests that seepage may account for it, augmented at time of rains by surface drainage, when it overflows. If the depth quoted is correct, the bottom is lower than that of any portion of Buzzard's Bay adjacent.

In several localities, notably in the vicinity of Tarpaulin Cove, the accumulation of bowlders is especially conspicuous, both for numbers and size, and they may be seen to advantage either where they are completely exposed on the shore [Plate $\mathbf{I X}$ ] or partially so in the adjacent hills, interspersed with patches of stunted Myrica cerifera L. [Plates X, XI]. "Fern Rock" is an immense bowlder, partly fractured and covered by a luxuriant growth of Polypodium milgare L., situated in a dense wood not far from West End Lake.

The general topography of the island is characteristically morainal and the larger part of the bowlders are granitic. Around the more sheltered north shore and in the coves and inlets, away from violent wave action, the beach shingle largely retains its original angular character as glacial dritt material and there is but little observable difference between it and material freshly washed out from the adjoining sloping banks, from the

ANmals N. Y. ACAD. SCI., XIII, Jan. 14, 190I-26. 
base of which there is a uniform grade to the water's edge, On the exposed southern shore however the shingle is rounded and water-wom and in places is thrown up into extensive ridges, beyond ordinary high-water mark, by wave action during storms, often masking the base of the adjacent blufis and causing an abrupt line of demarkation between the irregularly wave-tumbled, rounded beach shingle, and the steep face of the eroded moraine, with its angular ice-transported fragments. It is along this shore that erosion is proceeding most extensively, as may be readily seen in the steep escarpments of the bluffs which face it, and also in the rapid descent to deep water, as evidenced by the location of the submarine contours.

Inasmuch as these islands, considered as a whole, seemed to bear every indication of being simply a partly submerged and gradually disintegrating ridge in the morainal region south of the New England shore line, it was recognized that theoretically they ought to have the same general structure as the similar but larger ridge to the south, represented by Long Island, Block Island, Martha's Vineyard and Nantucket. In other words that the superficial morainal material ought to be found resting upon a superstructure of Cretaceous strata. A careful search was therefore made for.plastic clays and also for the ferruginous clay concretions and hardened fragments, which are invariably found under similar conditions in the islands mentioned. Such concretions were finally found on Nonamessett, and by tracing them up a bed of plastic clay, some of it highly lignitic, other portions brightly colored in reds and yellows, was found at the base of a bluff on the south shore, near the eastern end. No organic remains, other than the lignite were found, but the lithologic identity of the concretions and plastic clays with those of Gay Head, Block Island and Glen Cove was unmistakable. At no other locality was any indication of either the clays or the concretions discovered, although this is hardly to be wondered at considering the limited time given to the exploration. ${ }^{1}$

TThe only reference which I bave sees in regard to the occurreace of Cretuceous clays in the Elizabelh Islands is in a puper on "Glaciel Brick Clays of Rbode Island and Soutbenstem Masuchusets," by N. S. Stuler, J. B. Woodworth and C. F. 
Considered from the social standpoint the island constitutes a magnificent domain, easy of access and yet unspoiled by the destructive elements of civilization. It is a place in which deer and other wild creatures roam and breed freely amid natural surroundings and the general impression is that of a home of modem luxury and culture located in a wildemess, such as one would never expect to find in this part of the United States. ${ }^{1}$.

\section{Praque}

This island, owned by the Pasque Island Club, an organization devoted to striped bass fishing, has an area of about $1 \mathrm{r} / \mathrm{s}$ square miles and is entirely treeless, except for a small clump of Pinus sylvestris $\mathrm{L}$., which was planted near the club house, at the eastern end. It is a dome-shaped portion of the moraine, somewhat elongated in an east and west direction, with a maximum elevation of about 120 feet through the central axis and sloping irregularly in all directions to the shore line. In consequence there are no very high bluffs anywhere exposed and no sections of any extent are available fox study.

Swamps occupy many of the depressions, in which Clethra alnifolia. L, and Decodon verticillatus (L.) Ell. are conspicuous and Oxycoccus macrocarpus (Ait.) Pers. is plentiful. The hills are bare and wind-swept, resulting in a sort of turf composed of stunted herbaceous plants of several species, as well as grass, of which Solidago nemoralis Ait. and Aster cricoides L. are the most prominent constituents. Chrysopsis falcata (Pursh) Ell., Sericocarpus linifolius (L.) B. S. P., Hieracium Canadense Michx., $H$. Gronowii L. and Gyrostachys gracilis (Bigel) Kuntze, were also in sufficient abundance to be specially noticed.

The general superficial geological conditions are identical with

Marbut, in the 17th Annual Report of the Uaited Stutes Geological Survey, Part 1., Pp. 951-5004, where they ure incidentally mentioned on pp. 962 and 983, without, bowerer, giving any exect locality. On the latter page is dso figured a theoretical section through Buzzards' Bay, Neusbon, Vineyart Sound and Martha's Vineyard.

I Those who are interested in this pbase of the subject may find a reference to the social life of the island in Oliver Wendell Holmes' "Antocrnt of the Breakfingt Table," Chapter Il., and an illustrated popular accoust by Gusur Kobbe in the Contury Magavime, LVI (Sept., iBg8), 753-759. 
those of Naushon, but the entire absence of arborescent vegetation has caused the effects of rain and wind erosion to be more pronounced. Wherever the turf is destroyed erosion is rapid and depressions are soon formed by the removal of the finer material, leaving the bowlders prominently exposed.

Around the shores the effects of wave and wind action are very pronounced. In places where depressions have been reacherl by tide water, in the gradual recession of the shore line, these are often dammed by an accumulation of wave-thrown shingle and the result is the formation of a swamp or pond. [Plate XII.]. The dam is constantly pushing further and further inland and every stage in the evolution and final obliteration of such a swamp or pond may be seen. Often the old swamp deposit, with the water seeping through, may be found exposed on the slope of the beach at low tide--the sole reminder of these former conditions. Occasionally dune sand accumulates on the dams and vegetation obtains a foothold, in which case a compact barrier beach results.

Bolted firmly to the bowlders on the shore and in the adjacent water, and extending out for a considerable distance, are the fishing stands, each one provided with a seat, on which the fisherman may sit, and any description of the island would be incomplete without at least a brief reference to this feature. [Plate XIII.]

\section{Nashaweona}

This island, owned by Mr. Edward B. Merrill, is next in size to Naushon, having a length from east to west of about three miles and an average width of about one mile. The greatest clevations are about 125 feet, in a series of scattered hilltops, located towards the southwestem part of the island. Good sections of about 60 or 70 feet are exposed in the bluffs on the south shore near the west end, which show stratifed, grayish, sandy clays, similar to those which are prominent in Mohegan Bluffs on Block Island and at Montauk Point on Long Island, and on which the superficial bowlder till rests-the entire series representing the varying conditions which obtained during the Qua- 
ternary period. The probable age and conditions of deposition of these strata are well discussed in the report on "Glacial Brick Clays, etc.," previously quoted.

Although there is constant general erosion and recession of the coast line on all sides, there are places where land has evidently been making in recent times. This is noticeably the case at the east end of this island, where the former shore may be traced around the borders of the low swamp land in that vicinity, by means of the old beach shingle, now almost entirely hidden by extensive dune deposits. This was apparently a cove or embayment, before Quick's Hole had been broken through, and doubtless the formation of that channel so altered the previous conditions that new tidal currents were established and deposition began in places where erosion had previously prevailed. Quick's Hole, as well as each of the other channels between the islands, apparently began as coves on oppusite sides of the land, the shore lines of which gradually progressed inward, by reason of subsidence and erosion, until they finally met, when, a break once made, tidal scouring soon caused the formation of a channel. The relative locations of and conditions in connection with Tarpaulin and Kettle Coves, ori Naushon, indicate such a series of present and future effects.

Nashaweena rupports some quite extensive clumps of stunted trees, which are mostly massed in the depressions and on the sheltered slopes of the northeastern portion. The sheltered areas are more numerous and larger than on Pasque and vegetation in general is more abundant. It does not differ materially from that of Naushon, except for the greater relative abundance of aaks as compared with beeches. One or two holly trees were noticed, but I was unable to ascertain whether or not they were native. Probably the most conspicuous botanical feature was the masses of Clethra in the swamps. Water lilies were very abundant in the shallow ponds and mushrooms were to be found in nearly all the pastures. The only plant collected, however, to which particular attention need be called, was a single specimen of Centaurca arenaria Bieb., an introduced species, which I believe has not heretofore been reported from the United States. 
Except for one farm house there is no human habitation on the island; which is a complete wilderness, utilized only as a sheep range, but serving occasionally as a refuge for some of the deer from Naushon, which at times swim over from there.

\section{Ponikese}

This little island, now owned by Mr. Geo. S. Homer, is about $1 / 4$ square mile in area, and is probably most widely known as having been, during one period of its history; the home of Agassiz's school. It rises from the shore line on all sides to a height of some 85 feet near the center, and is about as barren and unattractive a pile of gravel and bowlders as can well be imagined. The only plant sufficiently conspicuous to attract my attention, was Solanum rostratutn Dunal, which was growing in abundance around the ruins of the old school.

Certain species of tems breed there in immense numbers, and while wandering over the nesting grounds I saw perhaps a score or more of this season's young ones hopping and fluttering over the grass and stones, evidently unable to fly. Several were picked up in order to examine them, and in each instance it was found that one or both wings were aborted. The number of these cripples was evidently considerable, as I saw the dead bodies of many others. All, of course, must have died of starvation as soon as they were finally deserted by the old ones. At the time of my visit the entire colony was yet there and the frightened cries of the cripples at once attracted all the birds in the vicinity, who formed a vast whirling cloud, hovering close overhead, individuals from the mass every now and then making closer downward swoops and all joining in making a deafening noise. It was a sight alone worth a journey to the island to see.

\section{Onttyhink}

. This island is the only one of the group which is divided amongst a number of owners. It has an area of about $11 / 2$ square miles and a maximum elevation, near the center of the eastem end, of about 150 feet. This elevation forms a bold headland, which slopes abruptly to the adjacent shores, while at 
its western end it merges into the central ridge which gradually becomes lower and lower until it reaches tide level. As these hills are absolutely destitute of trees, the sky line from almost any direction is peculiarly sharp and conspicuous. [Plate XIV, Iis. I.]

A sand spit of recent deposition is a prominent feature at the eastem end, which extends almost to Nashaweena, from which it is separated by Canapitsett Gut. As in the case of the similar deposit mentioned at the eastern end of Nashaweena, it is probably due to the eddies and currents which were established subsequent to the formation of the passage between the islands. Facing the southern and western shores there are precipitous bluffs, in which good sections are exposed. The material is entirely of glacial origin, but bowlders are fewer than on the islands to the eastward. The finer deposits are of grayish sandy clay, for the most part distinctly stratified.

Except for the few trees planted in the vicinity of the little settlement at the eastern end, the island is absolutely treeless, although there is abundant evidence that at one time it was well wooded. Near the westem end, on the south shore, is a depression once occupied by a swamp, one edge of which is exposed by the breaking away of the bluff. In the bottom of this depression may be seen numerous large stumps and logs, buried in a peat-like mass of fine vegetable debris, and subsequent microscopic examination of specimens collected showed these to be oak and beech.

In the "History of New Bedford, etc.," previously mentioned, there are numerous references to Bartholomew Gosnold's account of the island, which he called "Elizabeth Island." In Gabriel Archer's journal of Gosnold's voyage he says: "On the north side, near adjoining unto the island of Elizabeth, is an islet in compass half a mile, full of cedars, by me called Hill's Hap." [Penikese.] $\mathrm{He}$ also notes that Elizabeth Island [Cuttyhunk] was covered with trees-"oaks, ashes, beeches, walnut, witch-hazel, sassafras, and cedars, with divers other unknown, names."

In the account of the voyage writter by John Brereton he 
also describes Cuttyhunk as thickly wooded, principally with beech and cédar. They also found, he says: "red and white strawberries, as sweet and much bigger than ours in England," also raspberries, gooseberries and whortleberries. $\mathrm{He}$ next mentions the "great store of deer and other beasts, as appeared from their tracks". and finally states that they all grew fat on the young sea fowl which they found in nests upon the banks and in low trees.

\section{CONCLUSIONS}

If the superficial facts, as previously outlined, be considered in connection with the adjacent submarine contours, 'it may be readily seen that a comparatively slight elevation would cqmpletely drain the channels which now separate the islands from each other and from the mainland and would convert the entire series into a long peninsula, consisting of a range of morainal bills extending in a southwestern direction from Wood's Hole.

In order to emphasize this point I have prepared the accompanying map [Plate $\mathbf{X V}$ ] of the islands, showing the location of the 8-fathom contour, ${ }^{2}$ together with the few other soundings of greater depth in Buzzard's Bay and Vineyard Sound. From this it may be seen that if the 8-fathom contour be considered as the shore line of a previous period in the history of the region, not only would the islands form a continuous ridge of land, but this ridge would be considerably extended both in length and width and Buzzard's Bay would be almost obliterated.

If the windings of the contour be followed around it is evident that the indication of the first break which was made through the ridge is at Quick's Hole and that the area which includes Nashaweena, Cuttyhunk and Penikese formed one island before Pasque and Naushon had been separated from each other or from the mainland. Penikese was apparently the next to be isolated, then Cuttyhunk and Nashaweena, then Pasque and finally Naushon.

'See Coast Survey Chart No. 1r2. Vineyard Sound and Buzzard's Bay.

? Note. - My reason for teking the 8-fathom contour wes because a contour of apy greater depth would almost entirely elininate Buzrend's Bay as a former feature of the region. 
From the location of the islands and the general character and arrangement of the material of which they are composed, it is evident that they represent a partially submerged morainal ridge, probably a portion of the later, northern branch of the terminal moraine, represented by Orient Point on Long Island, Plum Island, Gull Islands and Fisher's Island. That these represent a more recent stage of glacial action than Montauk Point, Block Island and Martha's Vineyard is also strongly indicated by the almost total absence of Cretaceous material, which is so characteristic of the earlier or southem branch of the moraine. Nearly all of this material, on account of its incoherent character, would almost inevitably have been eroded on the first advance of the ice sheet over the Buzzard's Bay and Vineyard Sound area, and subsequently incorporated in the first moraine, as we find to be the case on Martha's Vineyard. A precisely similar case is also presented by the eastern end of Long Island, where the older branch of the moraine, represented by Montauk Point, contains practically all of the eroded cretaceous material, while the more recent branch, represented by Orient Point, contains almost none.'

Under the circumstances we may consider it as peculiarly fortuitious that the limited exposure of plastic clay on Nonamessett has been preserved, while the close proximity of this to the mainland indicates that there may yet remain some isolated patches which have resisted or escaped erosion, farther up the old estuaries, where theoretically the formation once extended.

Whether the ridge represented by the Elizabeth Islands was caused by an inequality in the crystalline rocks beneath we are hardly in a position to say, but reasoning from analogy the probabilities are against this idea and the inferential relations between thiese socks, the Cretaceous clays and the Drift deposits, according to the facts now in our possession, I have endeavored to indicate in the accompanying section from New Bedford to Martha's Vineyard. [Plate XIV, Iig. 2.]

1 For more extended discussion of this pbise or the subject see: Trans. $N . Y$. Acàd. Sii. XII (1893), 189-202; 222-237; XIII (1893), 8-22; (1894), 122132; XV (1895), 3-10; XVI (1896), 9-18 and Amm. N. Y. Acad. Sri, XI (1898), 55-88. 


\section{PLATE VIII.}

(403) 
PLATE VIII.

Sketch, showing bowlders and wind-contorted trees, south side of Naushon. Page 392.

(404) 


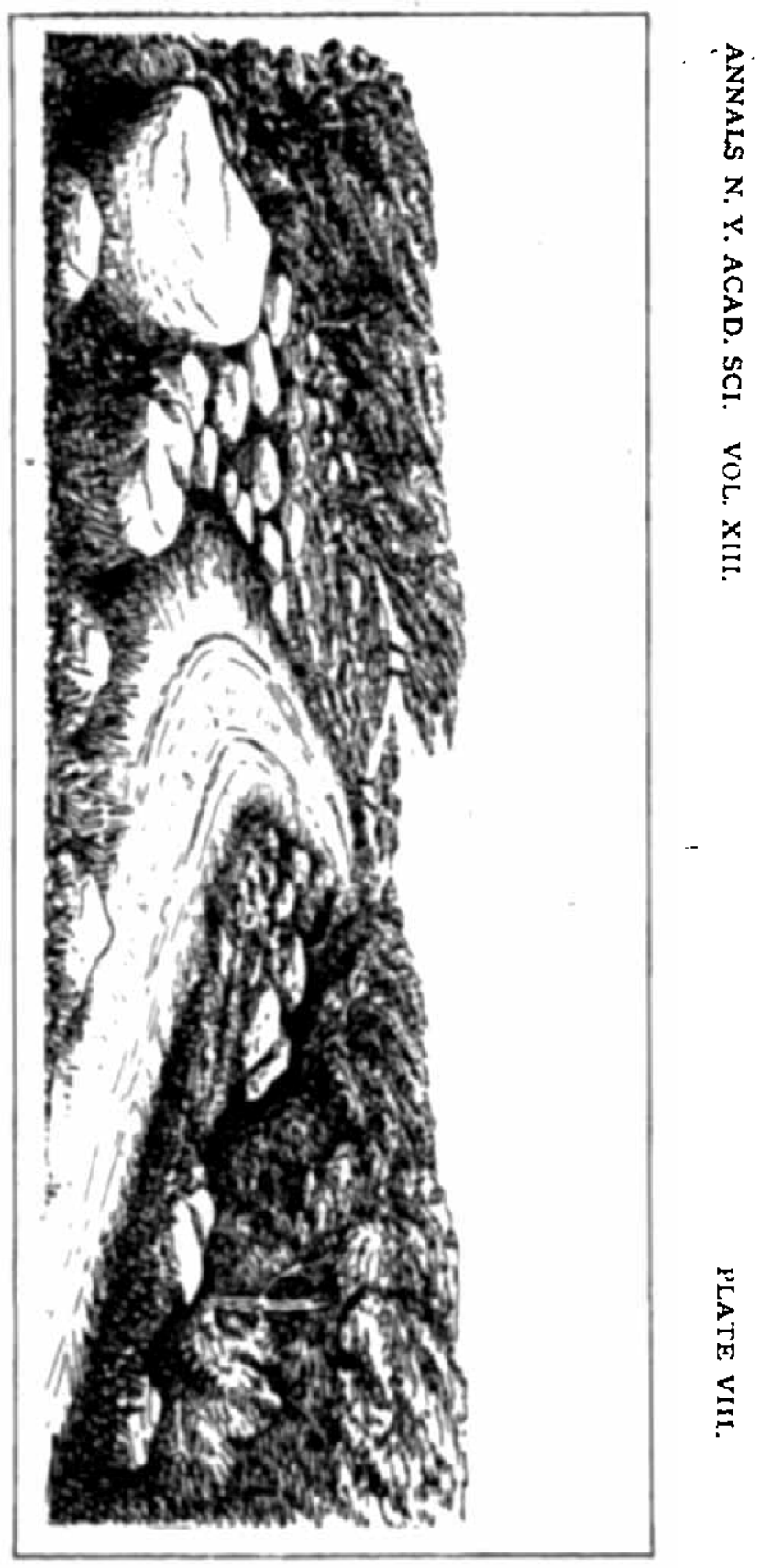




\section{PLATE IX.}

(405) 


\section{PLATE IX.}

View of the shore at Tarpaulin Cove, south side of Naushon, showing bowlders. Page 393.

(406) 


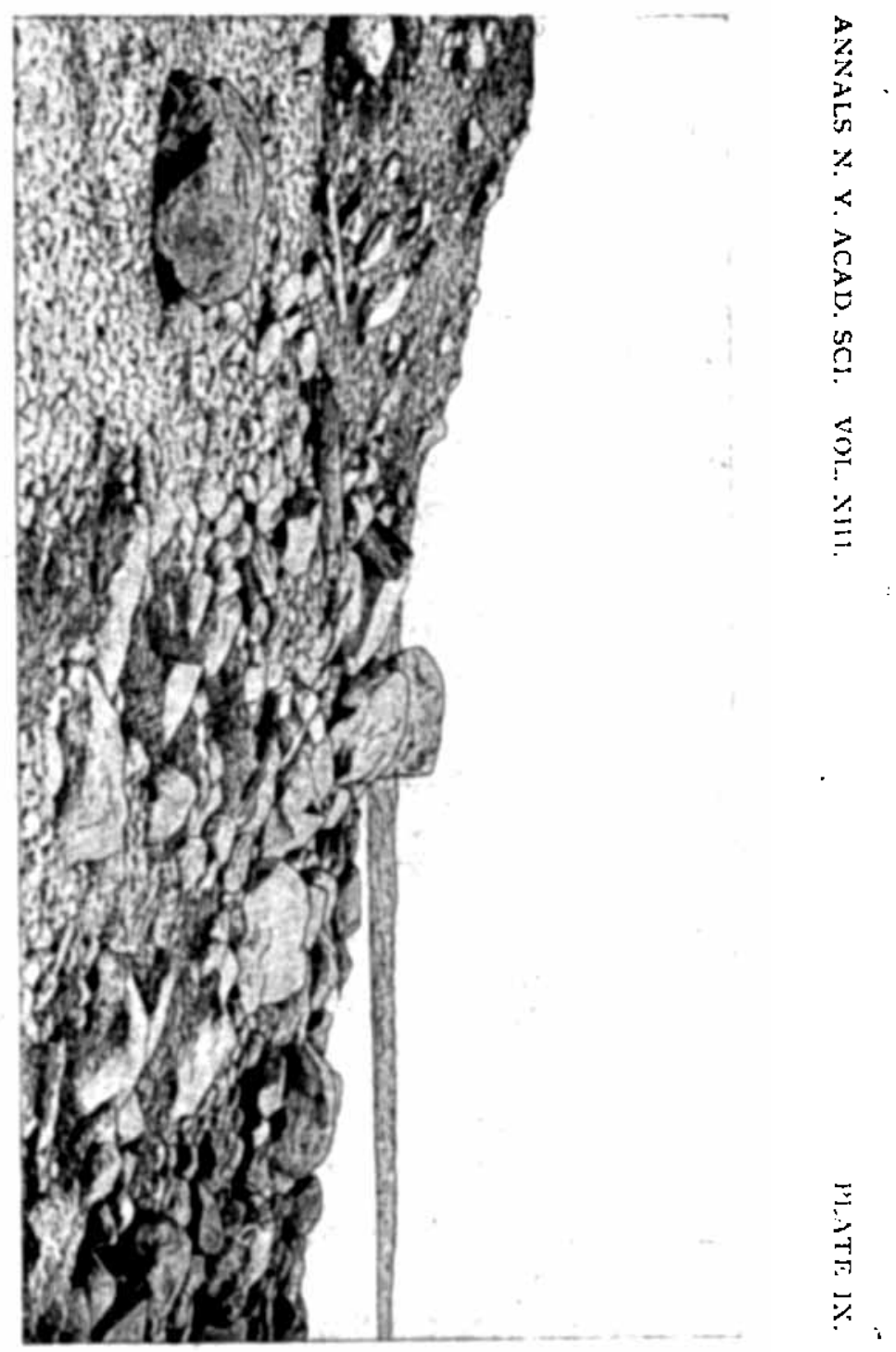




\section{PLATE X.}

(407) 


\section{PLATE X.}

View of a portion of the morainal hills, near Tarpaulin Cove, showing bowlders. Page 393.

(408) 


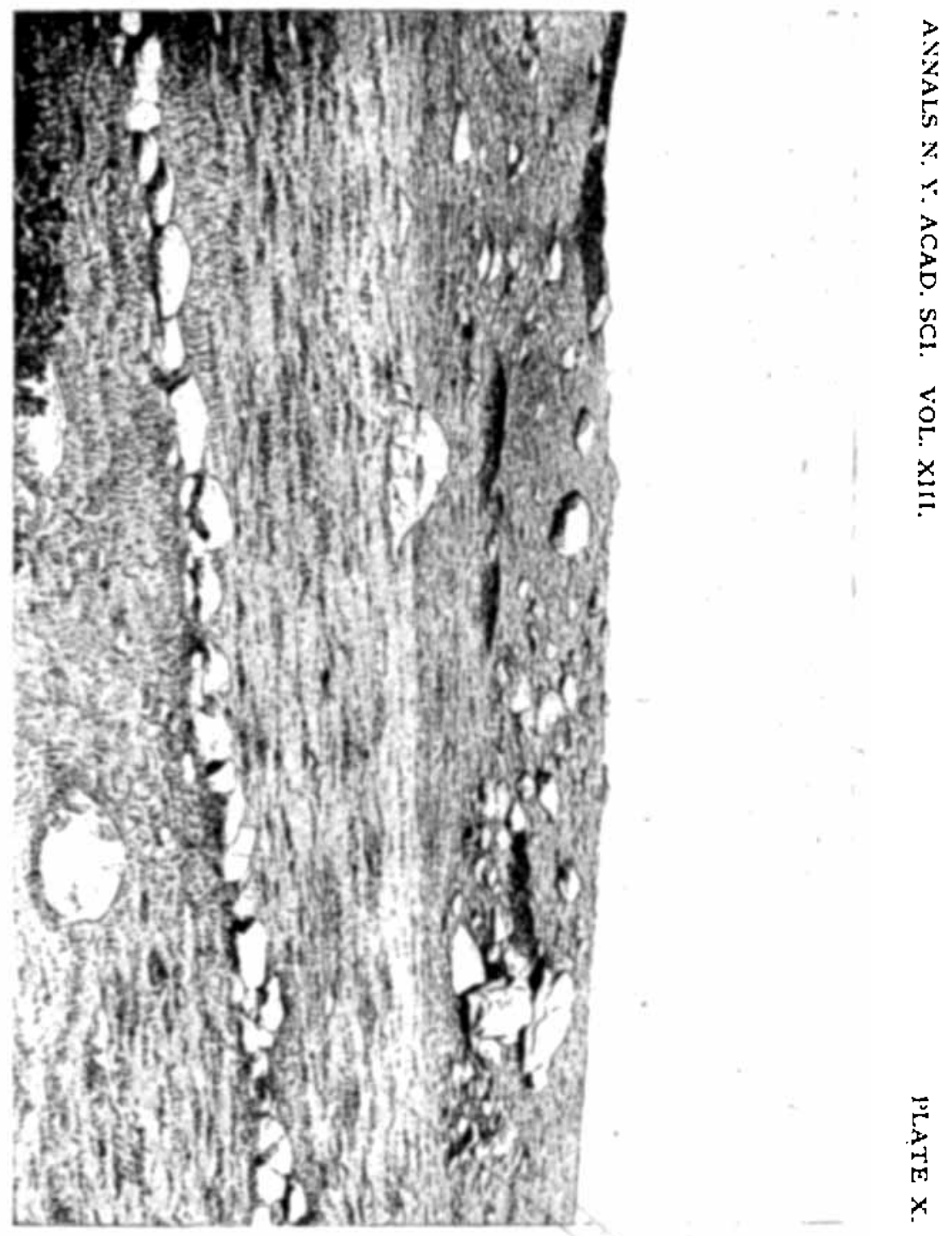




\section{PLATE XI.}

(409)

Awmals N. Y. ACAD. SCI, XIII, Jeo. 14, 1908-27 
PI.ATE XI.

View of a portion of the morainal hills, near Tarpaulin Cove, showing bowlders and patches of stunted Myrica cerifera L. Page 393 .

(410) 


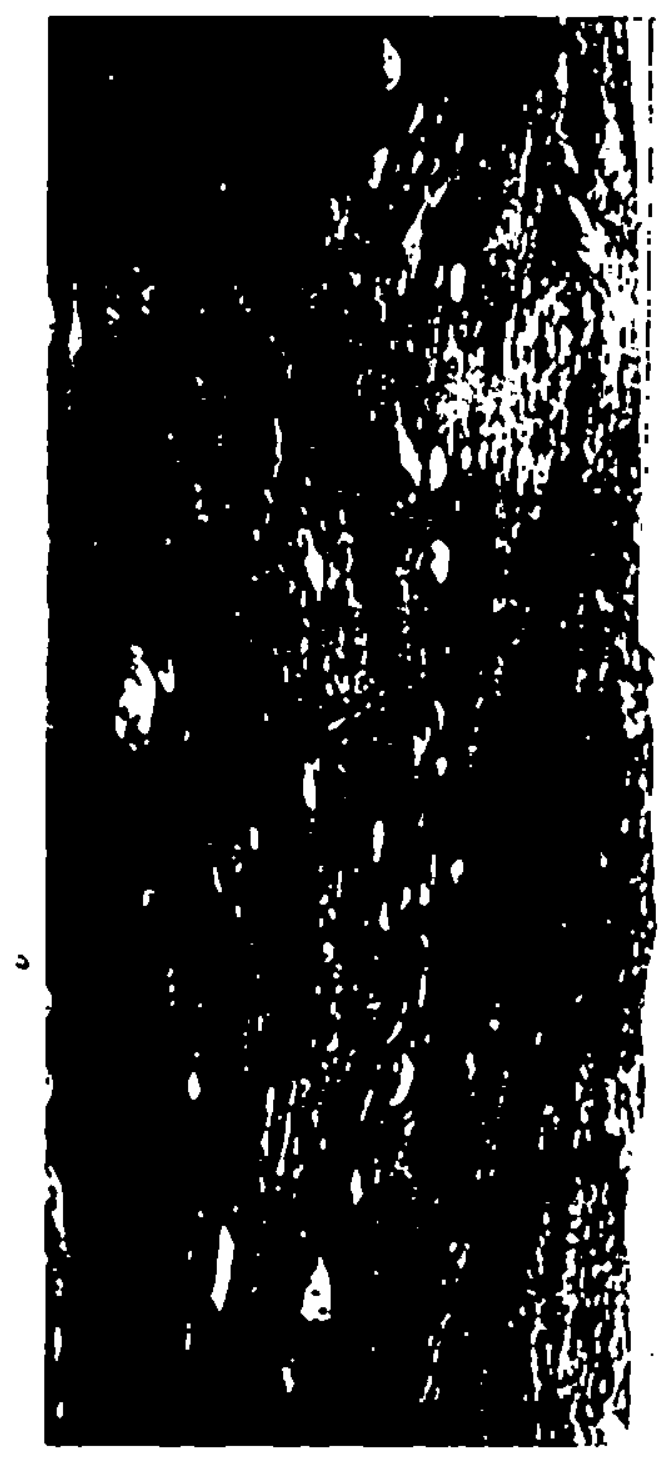

3
$\vdots$
$\vdots$
$\vdots$
$\vdots$
$\vdots$
$\vdots$
$\vdots$
$\vdots$
$\vdots$ 


\section{PLATE XII.}

(4II) 


\section{PLATE XIl.}

View of a portion of a depression, occupied by a swamp and dammed by a barrier beach. South shore of Pasqute. Page 396 .

\section{(412)}




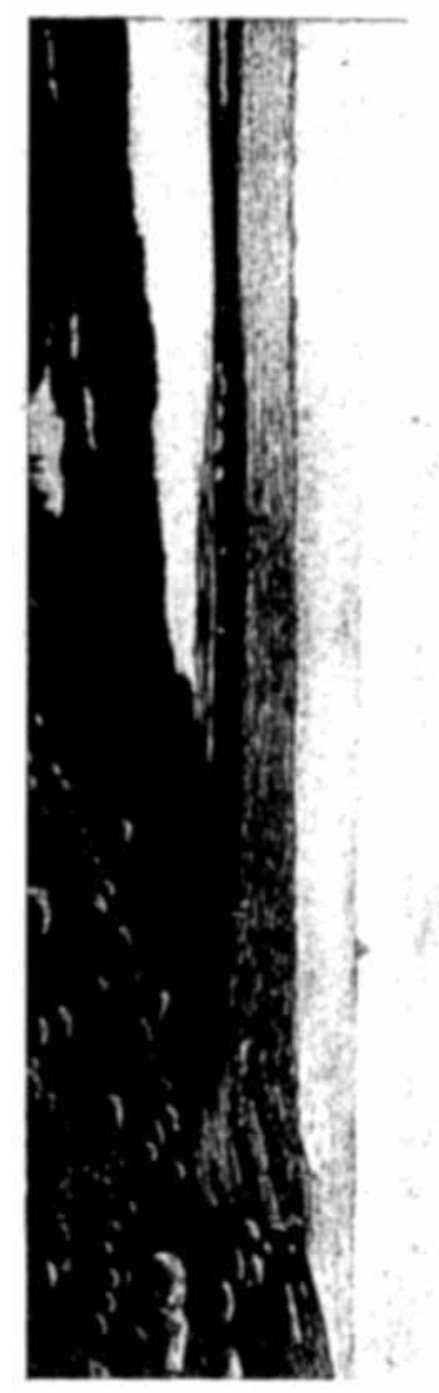

$\frac{1}{2}$

$=$
$\vdots$
$=$
$=$
$=$ 


\section{PLATE XIII.}

(418) 
PLATE XIII.

Sketch, showing bowlders and stands for striped bass fishing, south shore of Pasque. Nasheweena in the distance. Page 396.

(414) 


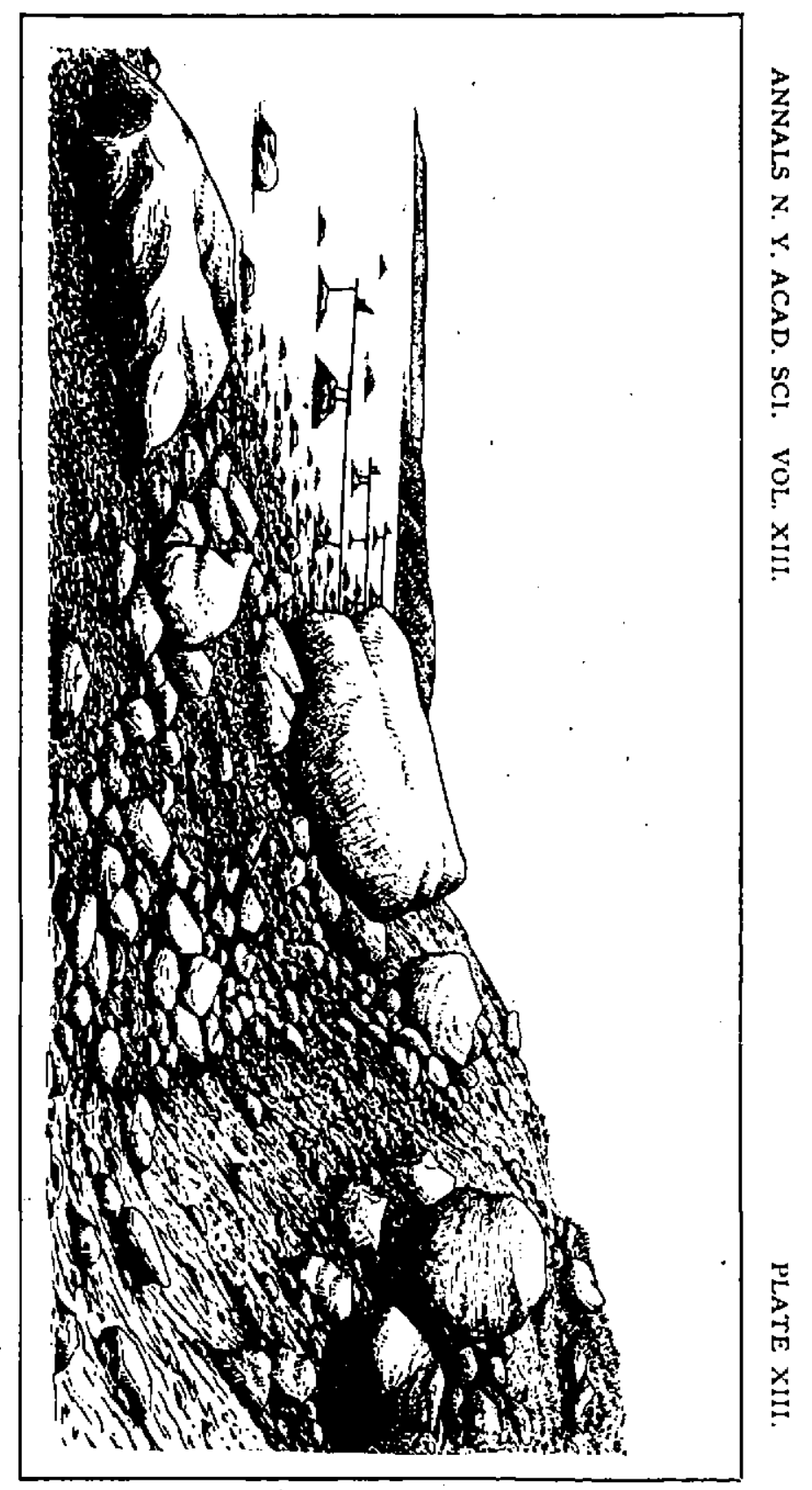


PLATE XIV.

(416) 


\section{PLATE XIV.}

Fic. 1. Sketch, showing the sky line of the central morainal ridge of Cuttyhunk, from northeast to southwest. Page 399.

Fic. 2. Geological section, from New Bedford to Martha's Vineyard, showing the theoretical relations between the Cretaceous clays, the crystalline rocks below and the Quaternary deposits above. Page 401 . 

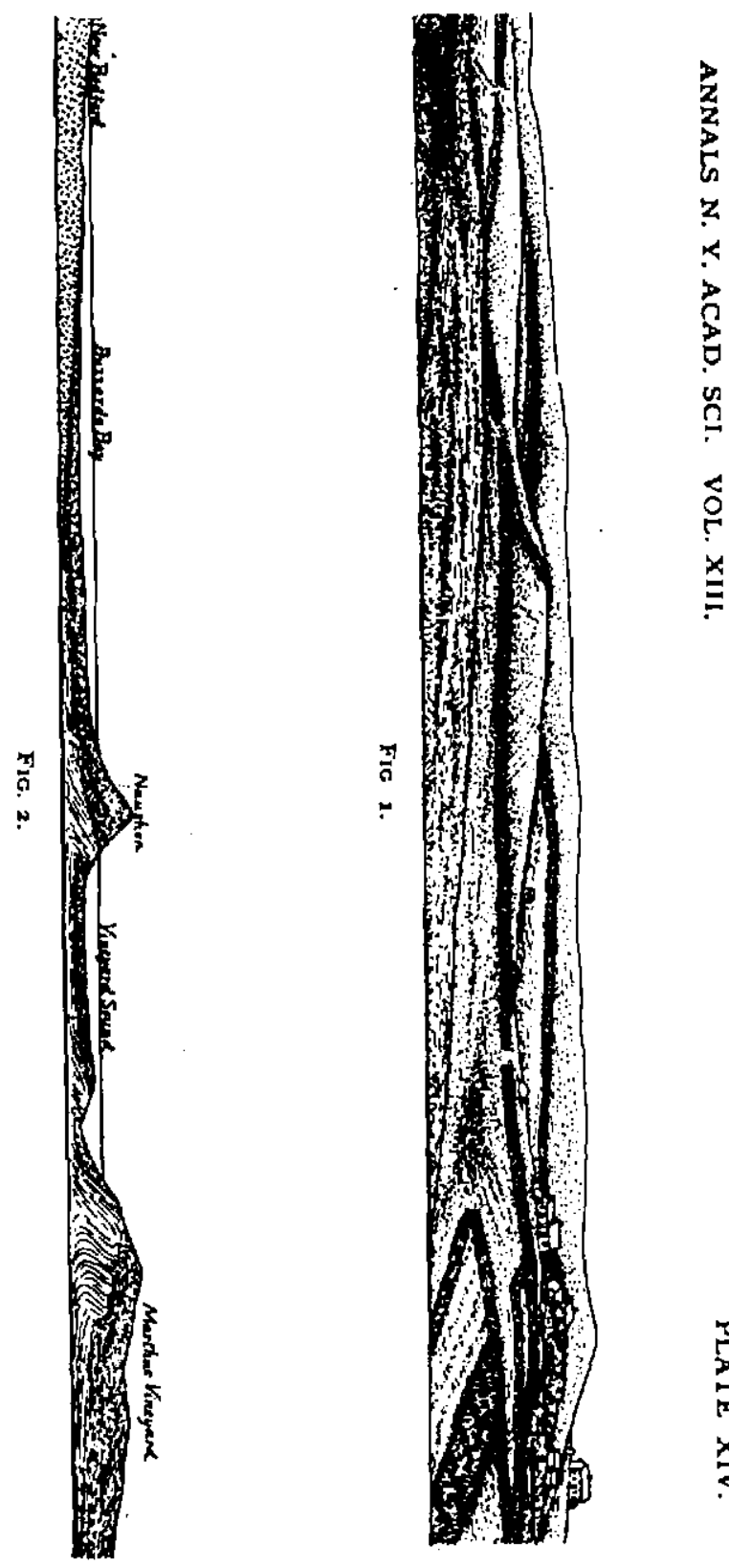

ลี

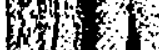

-
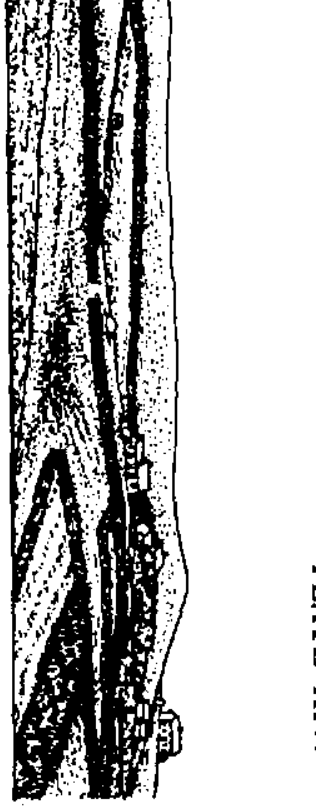

2

$\stackrel{x}{?}$ 
PLATE XV:

(417) 


\section{PLATE XV.}

Outline map of the Elizabeth Islands and vicinity, showing the location of the 8-fathom contour. Pages 390 and 400. 


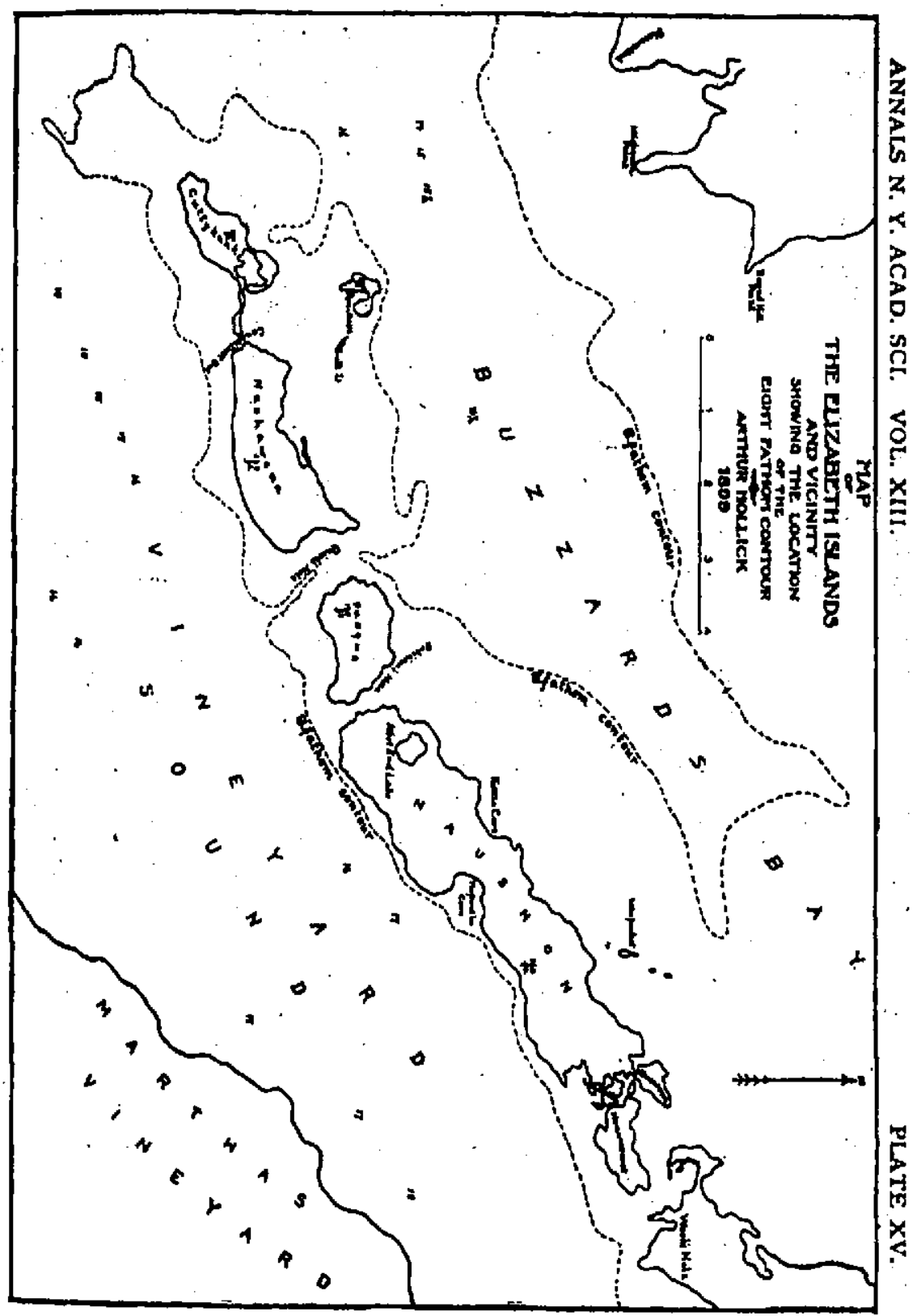

